\section{Nitrogen Contribution of Legume/Cereal Mixed Cover Crops and Organic Fertilizers to an Organic Broccoli Crop}

\author{
Joji Muramoto ${ }^{1}$ \\ University of California Santa Cruz, 1156 High Street, Santa Cruz, CA 95064
}

Richard F. Smith

University of California Cooperative Extension, Monterey County, 1432 Abbott Street, Salinas, CA 93901

Carol Shennan

University of California Santa Cruz, 1156 High Street, Santa Cruz, CA 95064

Karen M. Klonsky

University of California Davis, Department of Agricultural and Resource

Economics, Davis, CA 95616

James Leap

University of California Santa Cruz, 1156 High Street, Santa Cruz, CA 95064

Miriam Silva Ruiz

University of California Cooperative Extension, Monterey County, 1432 Abbott Street, Salinas, CA 93901

Stephen R. Gliessman

University of California Santa Cruz, 1156 High Street, Santa Cruz, CA 95064

Additional index words. organic farming, $\mathrm{N}$ management, $\mathrm{N}$ immobilization, broccoli [Brassica oleracea L. (Italica group)], pre-side-dress nitrate test (PSNT), net return

Abstract. Legume/cereal mixed winter cover crops are commonly used by organic growers on the central coast of California, but they are unable to provide sufficient nitrogen $(\mathrm{N})$ for a high $\mathrm{N}$-demanding vegetable crop such as broccoli and supplemental fertilizer application may be necessary. The goals of this project were to evaluate the contribution of $\mathrm{N}$ from a mixed legume/cereal cover crop (CC) and feather meal and blood meal as organic fertilizers (OF) to an organic broccoli crop and to evaluate economic benefits of $\mathrm{CC}$ and $\mathrm{OF}$ to the subsequent organic broccoli crop. Trials were conducted at two sites ( $A$ and $B$ ) with different management histories. Cover crops were grown over the winter and incorporated into the soil in the spring and subsequently broccoli [Brassica oleracea L. (Italica group)] was grown in 2006 at both sites and in 2007 at $B$ only. Cover crop and no $\mathrm{CC}$ treatments were grown with supplemental organic fertilizers at four fertility levels $(0,84,168$, and $252 \mathrm{~kg} \mathrm{~N} / \mathrm{ha}$ of OF) with four replicates. Generally broccoli head yields at A $\left(14.9\right.$ to $\left.26.3 \mathrm{Mg} \cdot \mathrm{ha}^{-1}\right)$ were higher than at $\mathrm{B}(0.7$ to 17.4 Mg.ha ${ }^{-1}$ in 2006 and 5.5 to $17.9 \mathrm{Mg} \cdot \mathrm{ha}^{-1}$ in 2007). Yield and aboveground biomass $\mathrm{N}$ were significantly increased by $O F$ at rates up to $168 \mathrm{~kg} \mathrm{~N} / \mathrm{ha}$ at $\mathrm{A}$ and to $252 \mathrm{~kg} \mathrm{~N} / \mathrm{ha}$ at $B$ and by $C C$ in 2006 at both sites but not in 2007 at B. Although $N$ content of the $C C$ was similarly low at A (2006) and at B (2007), immobilization of soil mineral $\mathrm{N}$ occurred only at $B$. This suggests that the addition of a low $N$ content $\mathrm{CC}$ was offset by high $\mathrm{N}$ mineralization from the soil at $\mathrm{A}$ with a long organic management history (greater than 33 years). Supplemental fertilizer applications may be necessary to achieve optimal yields, but the amount needed can be reduced by cover cropping in fields with a long history of cover crop-based organic management (A) or when cover crop $\mathrm{N}$ content is sufficiently high to prevent immobilization (B, 2006). Soil $\mathrm{NO}_{3}-\mathrm{N}$ patterns suggest a pre-side dress nitrate test may also be useful for $\mathrm{N}$ management in organic broccoli. Use of cover crops increased net return above harvest and fertility costs when the yield reduction by $\mathbf{N}$ immobilization did not take place. However, the net return increase by the use of cover crops tended to diminish as the rate of $O F$ application increased.

Nitrogen is the most common limiting plant nutrient and $\mathrm{N}$ fertility management is therefore an important but costly part of organic

vegetable production. Nitrogen for organic production is available from a number of sources: mineralization of $\mathrm{N}$ from soil or- ganic matter, compost, recently incorporated crop and cover crop residues, and various organic fertilizers. Cover crops can provide an inexpensive source of $\mathrm{N}$ for crop production (Smith, in press; Wyland et al., 1996).

Use of a legume/cereal mixed winter cover cropping is a common practice among organic growers on the central coast of California. Besides common benefits of cover crops such as improving soil and water quality (Cherr et al., 2006; Dabney et al., 2001; Fageria et al., 2005), erosion control (Bibro, 1991; Dabney, 1998; Delgado et al., 1999), and weed suppression (Bensen et al., 2009; Brennan and Smith, 2005; Brennan et al., 2009; Liebman and Davis, 2009), benefits of mixed winter cover cropping include the combination of atmospheric $\mathrm{N}_{2}$ fixation by leguminous cover crops and soil residual nitrate recycling by cereal cover crops (Ranells and Wagger, 1997; Tonitto et al., 2006). Furthermore, use of a legume/cereal mix often increases total cover crop biomass and $\mathrm{N}$ accumulation compared with monoculture of either leguminous or cereal cover crops (Gliessman, 1989; Karpenstein-Machan and Stuelpnagel, 2000; Sainju et al., 2005).

The effectiveness of cover crop residue in providing $\mathrm{N}$ for subsequent crop growth depends on the synchrony of release of $\mathrm{N}$ from the cover crop with crop $\mathrm{N}$ demand by the subsequent cash crop (Cherr et al., 2006; Crews and Peoples, 2005). Once incorporated into soil, the process of $\mathrm{N}$ mineralization from cover crop residue is regulated by adequate soil moisture and temperatures (i.e., greater than $10{ }^{\circ} \mathrm{C}$ ) and the $\mathrm{C}: \mathrm{N}$ ratio and other quality characteristics of the cover crop (Seiter and Horwath, 2004), making it difficult to predict precise $\mathrm{N}$ release dynamics. Work has shown that the rate of mineralization of available $\mathrm{N}$ from a low $\mathrm{C}: \mathrm{N}$ (less than $20)$ cover crop typically increases over a 3 - to 6-week period after incorporation and then returns to pre-incorporation levels by Week 6 to 8 in this region, the central coast of California (Gaskell, 2004). Therefore, a cover crop can be a valuable source of short-term $\mathrm{N}$ but longer season vegetable crops after a cover crop rotation may require supplemental applications of fertilizer $\mathrm{N}$ to supply late-season N (Delate et al., 2008; Schellenberg et al., 2009; Schonbeck et al., 1993; Scow et al., 1994; Smith, 1992; Temple et al., 1994).

A portion of the $\mathrm{N}$ added to the soil from cover crops may stay in the soil microbial biomass and organic matter fraction and only become available for subsequent cash crop growth many months after incorporation into the soil. For instance, the recovery of $\mathrm{N}$ from a cover crop may only be in the range of $8 \%$ to $28 \%$ for the first cash crop after incorporation (Bremer and Van Kessel, 1992; Crozier et al., 1998; Harris and Hesterman, 1990; Jackson, 2000; Ladd et al., 1983); however, one study using N15 showed that up to $73 \%$ of cover crop $\mathrm{N}$ was recovered in the five subsequent crops after incorporation of the cover crop (Crews and Peoples, 2005). Therefore, cover crops provide some $\mathrm{N}$ for immediate cash crop growth, but can also serve as a longer-term $\mathrm{N}$ source for crop growth in subsequent years. 
The central coast of California is a prime production area for broccoli [Brassica oleracea L. (Italica group)]. In 2007, Monterey and Santa Cruz Counties combined produced $\approx 30 \%$ of both conventional and organic broccoli in the United States by harvested acres (California Department of Food and Agriculture, 2010; USDA-NASS, 2009). We report on a study to evaluate the contribution of $\mathrm{N}$ from a mixed legume/cereal cover crop and organic fertilizer (feather meal + blood meal) to an organic broccoli crop and to evaluate the economic benefits of cover crop use.

\section{Materials and Methods}

Experimental sites, experimental design, and cultural practices. Trials were conducted at two sites with different management histories. Site A was located at the Center for Agroecology and Sustainable Food System organic farm on the University of California Santa Cruz campus (long. -122.0565, lat. 36.9831 , elevation $137 \mathrm{~m}$ ) from the winter of 2005 to the summer of 2006 . The soil type of the field is an Elkhorn sandy loam (Fineloamy, mixed thermic Pachic Agrixerolls) and the field had been managed organically for 33 years before the experiment. A complete randomized block design with four replicates was used with a CC (two levels; cover crops and no cover crops) and OFs [four levels; 0, 84, 168, and $252 \mathrm{~kg} \mathrm{~N} /$ ha with a combination of feather meal (pre-plant) and blood meal (in-season)] as treatment combinations. Each plot was $5.5 \mathrm{~m}$ wide $\times 5.0 \mathrm{~m}$ long and the total number of plots was 32 . Mixed legume/cereal cover crops were planted to the entire plot at a seeding rate of $199 \mathrm{~kg} \cdot \mathrm{ha}^{-1}$ on 17 Nov. 2005. The proportion by weight of the cover crop varieties was: $4 \%$ 'Cayuse' oats (Avena sativa); 48\% Bell beans (Vicia faba); and 48\% 'Lana' wooly pod vetch (Vicia villosa spp. dasycarpa) (Snow Seed Co., Salinas, CA). The cover crops were mowed down to the soil surface on 8 May 2006. Mowed cover crop residue (aboveground shoots) was removed from the trial site manually with rakes and a blower from the "without cover crop" on 10 May. We assumed $N$ release from the roots of the cover crop in "without cover crop" plots was small (less than $10 \%$ ) compared with $\mathrm{N}$

\footnotetext{
Received for publication 1 Mar. 2011. Accepted for publication 30 May 2011.

This project was funded by the USDA-OREI program (2004-51300-02232).

Mention of a trademark, proprietary product, or vendor does not constitute a guarantee or warranty of the product by authors' affiliated institutions and does not imply its approval to the exclusion of other products or vendors that also may be suitable.

We thank Timothy Hartz and Eric Brennan for valuable comments on an earlier version of the manuscript. Sara Emery, David Griese, Alexa Jones, Nicola Korte, Jeana Lee, Balyn Rose, Nebiyu Demissie, Jacob Edmonds, Jennifer Smith, and Evan Watson assisted with field and laboratory work at UC Santa Cruz for this project.

${ }^{1}$ To whom reprint requests should be addressed; e-mail joji@ucsc.edu.
}

release from the shoots (as noted by Puget and Drinkwater, 2001 and Sainju et al., 2005).

All plots were tilled with a mechanical spader (Celli S.p.A., Forlì, Italy) on 15 May. Beds $91 \mathrm{~cm}$ wide were formed by making two passes with a two-row Lilliston cultivator (Bigham Brothers, Inc., Lubbock, TX). The beds were then shaped with a two-row bed shaper (fabricated by James Leap) on 15 June. Each plot consisted of six beds $5 \mathrm{~m}$ long, the middle four beds of which were used for all soil and plant samplings. On the same day, feather meal (Phyta-Grow Super N 12-0-0; California Organic Fertilizers, Inc., Fresno, CA) was manually broadcast on the beds as a pre-plant $\mathrm{N}$. The fertilizer was applied at four rates: $0,56,112$, and $168 \mathrm{~kg} \mathrm{~N} / \mathrm{ha}$ and was rototilled into the beds immediately after application. Beds were shaped on 21 June and broccoli cultivar Bravado (Orsetti Seed Company, Inc., Hollister, CA) was direct seeded at $7.5-\mathrm{cm}$ spacing (double lines per bed) using Stanhay precision seeders (Stanhay Webb Ltd., Grantham, U.K.) on the same day. Sprinkler irrigation was used to germinate the seed. Broccoli plants were thinned to $22.5-\mathrm{cm}$ spacing on 10 and 11 July (plant density: 80,600 plants/ha) and then high-flow drip tape (single line per bed) was installed. The trial was irrigated with 4 to $10 \mathrm{~mm}$ of water every 2 to $3 \mathrm{~d}$ for the duration of the crop cycle. Blood meal (Phyta-Grow Big Red 12-0-0; California Organic Fertilizers, Inc.) was side-dressed on 25 July as an in-season $\mathrm{N}$ supplement at four rates: $0,28,56$, and $84 \mathrm{~kg} \mathrm{~N} /$ ha making total OF (feather meal plus blood meal) application rates of $0,84,168$, and $252 \mathrm{~kg} \mathrm{~N} / \mathrm{ha}$. A total of $168 \mathrm{~kg} \mathrm{~N} / \mathrm{ha}$ represents a typical rate for organic broccoli in this area (Tourte et al., 2004 ) and $\mathrm{N}$ rates were chosen to cover $0 \%$, $50 \%, 100 \%$, and $150 \%$ of the typical rate. Broccoli shoots were sampled for biomass and $\mathrm{N}$ uptake evaluation on 25 July (early growth), 16 Aug. (midgrowth), and 18 Sept. (harvest). Harvest evaluation was made from two 3-mlong sections in each plot on 19 Sept. 2006. Broccoli heads were harvested with $15 \mathrm{~cm}$ of stem, which made the head length $\approx 20 \mathrm{~cm}$.

The second site, B, was at the Hartnell East Campus Research Facility in Salinas (long. -121.6064, lat. 36.6704, elevation $26 \mathrm{~m}$ ). Two trials were conducted, the first from winter 2005 to summer 2006 and the second from winter 2006 to summer 2007 using the same plots. Before the experiment, the site had been used for cover crop trials for 5 years. The soil type is Chualar loam (Fine-loamy, mixed, thermic Typic Argixerolls). A splitplot randomized block design with four replicates was used with cover crop and no cover

Table 1. Baseline soil characteristics of Sites A (Santa Cruz, CA) and B (Salinas, CA) at 0- to 30-cm depth. ${ }^{2}$

\begin{tabular}{|c|c|c|c|c|c|c|c|c|c|}
\hline \multirow[b]{2}{*}{ Site } & $\mathrm{TC}$ & $\mathrm{TN}$ & \multirow[b]{2}{*}{$\mathrm{pH}$} & \multirow{2}{*}{$\begin{array}{l}\mathrm{EC}(\mathrm{SP}) \\
\left(\mathrm{dS} \cdot \mathrm{m}^{-1}\right)\end{array}$} & \multirow{2}{*}{$\begin{array}{l}\text { Olsen-P } \\
\left(\mathrm{mg} \cdot \mathrm{kg}^{-1}\right)\end{array}$} & Ex.Ca & Ex.Mg & Ex.K & Ex.Na \\
\hline & & & & & & \multicolumn{4}{|c|}{$\left(\mathrm{cmol} \cdot \mathrm{kg}^{-1}\right)$} \\
\hline$\overline{\mathrm{A}}$ & 9.4 & 0.98 & 6.3 & 0.82 & 40.0 & 5.27 & 0.81 & 0.58 & 0.085 \\
\hline B & 13.9 & 1.10 & 7.4 & 1.51 & 60.3 & 12.3 & 2.71 & 0.36 & 0.73 \\
\hline
\end{tabular}

${ }^{\mathrm{z}}$ Soil sample from Site A was taken on 5 July 2005 and from B on 1 Dec. 2005.

$\mathrm{TC}=$ total carbon; $\mathrm{TN}=$ total nitrogen; $\mathrm{pH}=\mathrm{pH}$ (saturated paste); $\mathrm{EC}=$ electrical conductivity (saturated paste); Olsen-P = olsen-phosphorus; Ex.Ca = exchangeable calcium; Ex.Mg = exchangeable magnesium; Ex.K $=$ exchangeable potassium; Ex.Na = exchangeable sodium. crop as the main plots and $0,84,168$, and 252 $\mathrm{kg} \mathrm{N} / \mathrm{ha}$ as the split-plot treatment. Each subplot was $4.1 \mathrm{~m}$ wide $\times 12 \mathrm{~m}$ long and the total number of plots was 32 . For the 2005-2006 season, a mixed legume cover crop was planted in cover crop plots at the rate of $123 \mathrm{~kg} \cdot \mathrm{ha}^{-1}$ on 11 Oct. 2005. The proportion of varieties by weight was the following: $18 \%$ 'Cayuse' oats; $38 \%$ Bell beans; $20 \%$ 'Lana' wooly pod vetch; 'Magnus pea (Pisum sativum) (L.A. Hearne Company, King City, CA). The noncover cropped plots were rototilled twice during the winter to control weeds. The cover crops were mowed and rototilled into the soil 14 Feb. 2006. Beds $102 \mathrm{~cm}$ wide were Implements, Buttonwillow, CA) and all plots were divided into four fertilizer subplots that were four beds wide $\times 12 \mathrm{~m}$ long. Feather meal (Phyta-Grow Super N 12-0-0; California Organic Fertilizers, Inc.) was applied at 0,84 168 , and $252 \mathrm{~kg} \mathrm{~N} / \mathrm{ha}$ with a small plot fertilensing two shanks $7 \mathrm{~cm}$ to the side of each sideline and $15 \mathrm{~cm}$ deep on 20 Apr.. The beds were shaped with a Marvin bed (Marvin Landplane Company, Woodland, CA) the same day. Broccoli transplants of Inc., Morgan Hill, CA; 54-d-old plants) were planted by hand at $15-\mathrm{cm}$ spacing on $21 \mathrm{Apr}$. (plant density: 125,475 plants/ha). Sprinkler irrigation was applied after transplanting to set the plants and was used for the rest of the $\mathrm{mm}$ per irrigation. pled for biomass and $\mathrm{N}$ uptake evaluation on 23 May (midgrowth) and 5 July (harvest). Harvest evaluations were conducted on 30 June and 5 July 2006 in a 7.5-m-long section in each plot.

In 2006-2007, the trial was repeated using the same production methods described previously and on the same plots. Mixed cover crops were planted on 22 Oct. 2006 and were war. 2007. Beds were formed beds on 17 Apr. Broccoli cv. Marathon was May and yield evaluations were conducted on 29 June and 3 July 2007. Sprinkler irrigation was used for the entire growth period of broccoli as for the previous year. See Table 1 for the baseline soil characteristics and Table 2 for weather data and total irrigation
during the growth periods for both sites.

Soil and plant sampling and analysis. At both sites, 0 - to $30-\mathrm{cm}$ depth soil samples from each plot were taken weekly starting immediately after cover crop incorporation and continuing until the broccoli harvest each and feather meal fertilizers were shanked into Midgrowth plant samples were taken on 22 
Table 2. Average maximum and minimum air temperatures, precipitation, and irrigation applied during growth periods of cover crops and broccoli at Sites $\mathrm{A}^{\mathrm{z}}$ and $\mathrm{B}^{\mathrm{y}}$.

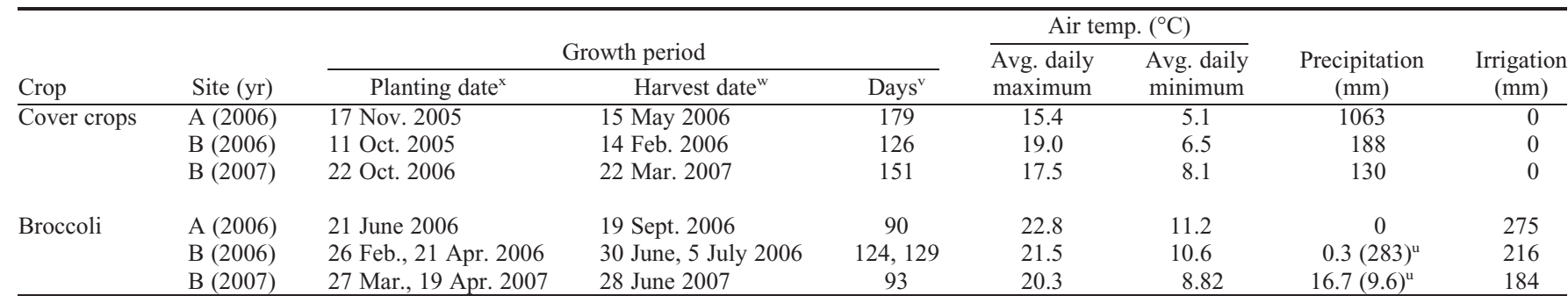

${ }^{2}$ Weather data from California Irrigation Management Information System (CIMIS) station \#104, De Laveaga, Santa Cruz A (5.6 km from Site A).

${ }^{\mathrm{y}}$ Weather data from CIMIS station \#89, Salinas South, Salinas A (7.5 km from Site B).

${ }^{\mathrm{x}}$ Seeding dates and transplanting dates for broccoli at Site B.

"Incorporation dates for cover crops. There were two harvest dates for broccoli at Site B in 2006.

'Days from seeding date for broccoli at Site B.

"Number in parentheses indicates precipitation during the seeding date and the transplanting date of broccoli.

season using a soil probe $(2 \mathrm{~cm}$ diameter). For each plot, eight subsamples were taken from the middle four beds (one per row $\times$ two rows per bed $\times$ four beds) to make a composite soil sample. After mixing well in a bucket, $\approx 5 \mathrm{~g}$ of soil was taken from the composite sample and transferred into a pre-weighed screw top plastic tube containing a $25 \mathrm{~mL}$ of $2 \mathrm{M} \mathrm{KCl}$ on site and shaken for $1 \mathrm{~min}$. After tightly closing the screw top, each tube was kept on ice in an ice chest and transferred to the laboratory. In the laboratory, samples were reweighed and kept at $4{ }^{\circ} \mathrm{C}$ until extraction that was done within 24 $\mathrm{h}$ of the sampling. $\mathrm{NH}_{4}-\mathrm{N}$ and $\mathrm{NO}_{3}-\mathrm{N}$ concentration in the $\mathrm{KCl}$ extracts were determined by flow injection analysis methods (Lachat Intruments, 1993a, 1993b). Separately $\approx 100 \mathrm{~g}$ of soil was taken from the composite sample to determine gravimetric soil moisture content.

Biomass and total $\mathrm{N}$ content of the cover crops were measured before incorporation. Cover crops were sampled from each plot using two $0.25-\mathrm{m}^{2}$ quadrats per plot and oven-dried in a forced-air oven at $60{ }^{\circ} \mathrm{C}$ until fully dry and then weighed to determine biomass. After grinding with a Wiley mill, total $\mathrm{N}$ content in biomass was measured by the dry combustion method (International Organization for Standardization, 1998). For broccoli, eight shoot samples per plot were taken at early (A only), midgrowth, and harvest (A and B, see previously for dates) and the biomass and $\mathrm{N}$ content were determined as for cover crop samples. Average daily $\mathrm{N}$ uptake rates by broccoli shoots ( $\mathrm{kg} \mathrm{N} / \mathrm{ha} / \mathrm{d})$ were calculated by the difference in biomass $\mathrm{N}$ ( $\mathrm{kg} \mathrm{N} / \mathrm{ha}$ ) across two successive sampling points during the growth period.

Apparent $\mathrm{N}$ recovery of cover crops and organic fertilizer (\%) was calculated as follows:

Apparent cover crop $\mathrm{N}$ recovery $(\%)=$ $\{[(\mathrm{kg} \mathrm{N} / \mathrm{ha}$ in broccoli shoot biomass at X $\mathrm{kg} \mathrm{N} /$ ha fertilizer plot with cover crops) ( $\mathrm{kg} \mathrm{N} /$ ha in broccoli shoot biomass at $\mathrm{X} \mathrm{kg}$ $\mathrm{N} /$ ha fertilizer plot without cover crops)]/ $\mathrm{kg} \mathrm{N} / \mathrm{ha}$ in cover crop aboveground biomass $\} \times 100$ and

Apparent organic fertilizer $\mathrm{N}$ recovery $(\%)=\{[(\mathrm{kg} \mathrm{N} / \mathrm{ha}$ in broccoli shoot biomass at $\mathrm{X} \mathrm{kg} \mathrm{N} /$ ha plot $)-(\mathrm{kg} \mathrm{N} / \mathrm{ha}$ in broccoli shoot biomass at $0 \mathrm{~kg} \mathrm{~N} / \mathrm{ha}$ plot)/]/X kg $\mathrm{N} / \mathrm{ha}\} \times 100$ where $\mathrm{X}$ is $\mathrm{N}$ application rate of fertilizer treatment.

Statistical analysis. Head yield, head weight, $\mathrm{N}$ in broccoli shoot biomass, and soil mineral $\mathrm{N}$ data were subject to analysis of variance and linear and quadratic regression analyses to determine the effect of $\mathrm{N}$ rates with or without cover crops. For each cover crop treatment, the best-fitted regression across OF treatments was selected based on a partial $F$ test on the effect of the addition of a chi-squared term to the linear model at $P=0.05$ (Kleinbaum et al., 1998). Statistical analysis program STATISTIX 9.0 (Analytical Software, 2008) was used for these statistical analyses.

Economic analysis. Effect of cover crops and $\mathrm{OF}$ on gross returns, harvest and fertility costs, and net returns above harvest and fertility costs in organic broccoli was estimated based on the sample cost studies of organic broccoli production on the central coast region of California (Tourte et al., 2004) in which a typical farm size, farming practices, and conventional market prices in the area are assumed. Yields and cultural costs data, including fertilizer costs and cover cropping costs from each plot of our experiment, were entered into the simulation model to estimate the expected income, costs, and net returns for a commercial size farm adopting the practices of each of the research plots. Harvest costs were adjusted according to yields. We assumed one broccoli crop per year, cover cropping every winter, and a value of $\$ 10.00$ per $10 \mathrm{~kg}$ (=22 lbs) box of organic broccoli. Other costs such as planting and thinning were not included in the analysis because they did not vary across treatments by location.

\section{Results and Discussion}

Cover crop yield and nitrogen content. Cover crop biomass was relatively consistent with values of $8.3 \mathrm{Mg} \cdot \mathrm{ha}^{-1}$ dry biomass ( $\mathrm{B}$ in 2007), 7.7 (A, 2006), and 7.2 (B, 2006). On the other hand, $\mathrm{N}$ concentration in cover crop biomass was higher in B in $2006\left(31 \mathrm{~g} \cdot \mathrm{kg}^{-1}\right)$ than the other two trials $\left(21 \mathrm{~g} \cdot \mathrm{kg}^{-1}\right)$. Consequently, $\mathrm{N}$ in biomass per hectare values were higher at B than A in 2006 (219 compared with $160 \mathrm{~kg} \cdot \mathrm{ha}^{-1}$ ) and higher in 2006 than 2007 for B (219 compared with $172 \mathrm{~kg} \cdot \mathrm{ha}^{-1}$ ).
Biomass of legume/cereal mixed winter cover crops in central coastal California is typically over $170 \mathrm{~kg} \mathrm{~N} / \mathrm{ha}$ (Smith, in press).

Broccoli yield. Broccoli head yield and head weight were much greater at $\mathrm{A}$ as compared with B (Fig. 1A). Head yields at A ranged from 14.9 to $26.3 \mathrm{Mg} \cdot \mathrm{ha}^{-1}$, whereas those at $\mathrm{B}$ ranged from 0.7 to $17.4 \mathrm{Mg} \cdot \mathrm{ha}^{-1}$ in 2006 and from 5.5 to $17.9 \mathrm{Mg} \cdot \mathrm{ha}^{-1}$ in 2007. Except for the 0 and $84 \mathrm{~kg} \mathrm{~N} / \mathrm{ha}$ plots at B in both years, head yield reached or exceeded the typical local yield range of organic broccoli (12.3 to $22.2 \mathrm{Mg} \cdot \mathrm{ha}^{-1}$; Tourte et al., 2004). The average fresh market broccoli yield (conventional + organic) in Monterey County in 2006 and 2007 was $17 \mathrm{Mg} \cdot \mathrm{ha}^{-1}$ (Monterey County Agricultural Commissioner, 2007). Notably, yield in the control (no cover crop $+0 \mathrm{~kg} \mathrm{~N} / \mathrm{ha}$ ) at $\mathrm{A}$ was $14.9 \mathrm{Mg} \cdot \mathrm{ha}^{-1}$, whereas at B it was 0.7 and $5.5 \mathrm{Mg} \cdot$ ha $^{-1}$ in 2006 and 2007, respectively. This may be attributed to a combination of higher inherent soil $\mathrm{N}$ mineralization at $\mathrm{A}$ and greater $\mathrm{N}$ loss by the long spring rain in 2006 at B. Difference in plant density between A ( 80,600 plants/ha $)$ and B $(125,475$ plants/ha $)$ might have affected the head yield. However, results of studies on the effect of plant density on broccoli yield are mixed. Dufault and Waters (1985) found that increasing plant densities decrease the head size but increased marketable yield of broccoli. In contrast, Cutcliffe (1971) found little effect of plant density on marketable yield for densities ranging from 39,000 to 242,000 plants/ha. At site B, older transplants were used in 2006 (54-d-old) than in 2007 (23-d-old), but studies have shown mixed results as to the effect of transplant age on broccoli yield (Jones et al., 1991; Kano et al., 2008; Kaymak et al., 2009; Lamont, 1992). Average harvest index of broccoli (on a fresh weight basis) at Site A, Site B in 2006, and Site B in 2007 was 0.34, 0.16 , and 0.24 , respectively. The difference may be partially attributed to the difference in plant density between the two sites.

Broccoli head yield and head weight increased linearly with increasing rate of fertilizer application at both sites in $2006(P<0.05)$ for head yield (Fig. 1A) and head weight (data not shown). Statistical comparisons of linear regression lines of cover crop plots and no cover crop plots for head yield showed that 

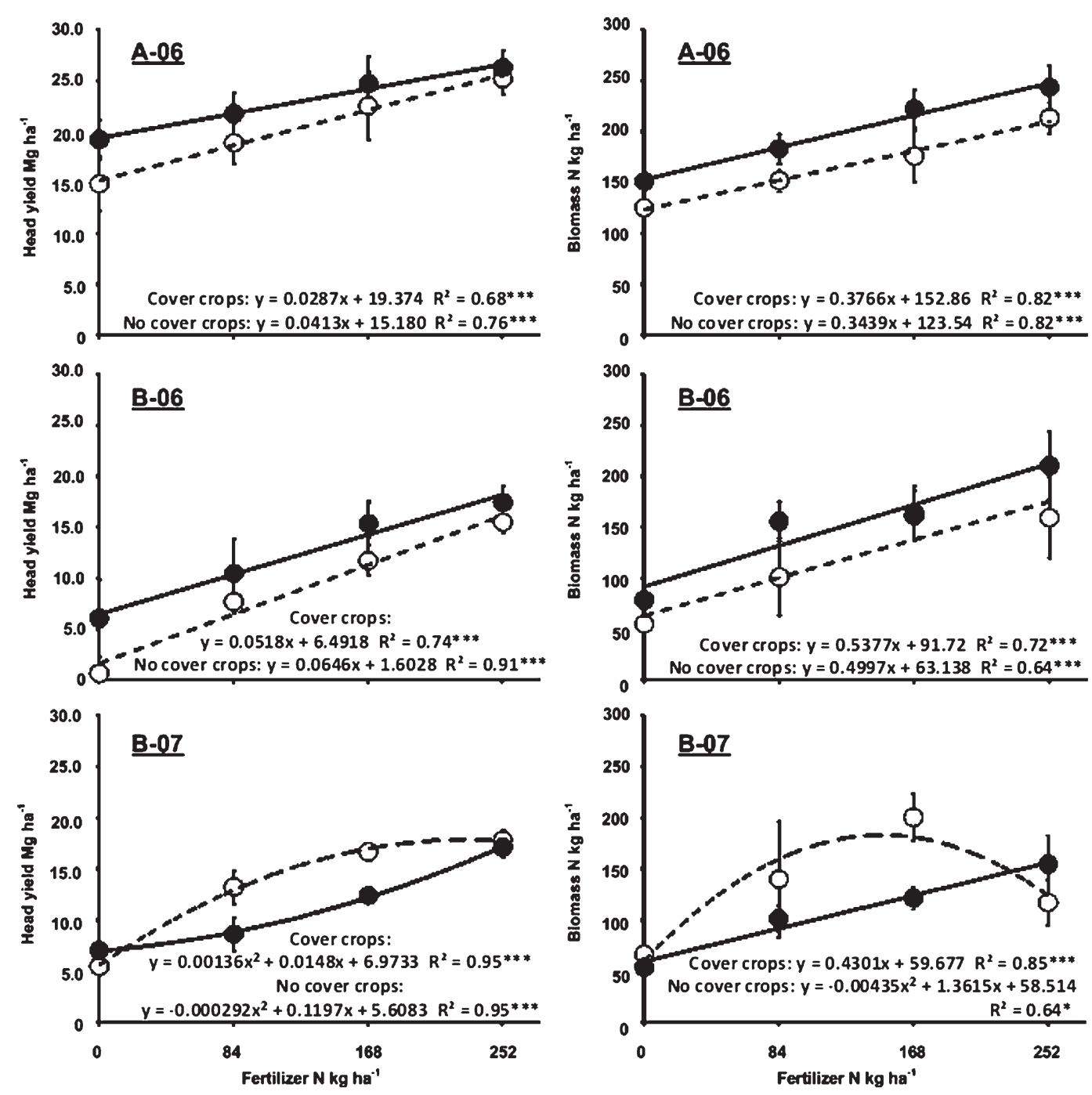

A. Head yield

B. Blomass N

Fig. 1. Response of broccoli to nitrogen (N) fertilization rates with or without cover crops at Site A (top, A-06) and Site B in 2006 (middle, B-06) and Site B in 2007 (bottom, B-07). (A) Head yield and (B) biomass N. Closed symbols with a solid regression line are with cover crops and open symbols with a dashed regression line are without cover crops. Each point is the average of four replicates $\pm \mathrm{SD} *, * *, * * *$ Significant at $P \leq 0.05,0.01$, or 0.001 , respectively.

slopes of regression lines were similar but the intercepts were significantly larger in the cover cropped treatments $(P<0.05)$. This difference in intercept reflects the increased broccoli yield with cover crops with cover crop yields being about equivalent to yields without cover crops with an additional $84 \mathrm{~kg}$ N/ha applied (Fig. 1A). In 2007 at Site B, although overall there was no significant cover crop effect $(P<0.17)$, head yields and head weights tended to be higher in the no cover crops plots than in cover crops plots, probably as a result of $\mathrm{N}$ immobilization (see subsequently). In addition, at B in 2007, broccoli head yield and head weight tended to increase curvilinearly with increasing rate of fertilizer application $(P<0.05$; Fig. 1A) for head yield.

Nitrogen uptake by broccoli. At Site A, average $\mathrm{N}$ uptake rate of broccoli during the first month of the crop cycle was 0.3 to $0.4 \mathrm{~kg}$ $\mathrm{N} / \mathrm{ha} / \mathrm{d}$ regardless of treatment (Fig. 2, top). However, both cover crop and fertilizer applications increased $\mathrm{N}$ uptake rates to a max- imum of 3.6 to $5.1 \mathrm{~kg} \mathrm{~N} / \mathrm{ha} / \mathrm{d}$ during the second month followed by a decline in the third (last) month to 1.3 to $3.8 \mathrm{~kg} \mathrm{~N} / \mathrm{ha} / \mathrm{d}$. At Site $\mathrm{B}$, average $\mathrm{N}$ uptake rates were only calculated during the last $\approx 40 \mathrm{~d}$ (midseason to harvest). During that time, $\mathrm{N}$ uptake rates increased as fertilizer rates increased from 0.8 to $2.9 \mathrm{~kg} \mathrm{~N} / \mathrm{ha} / \mathrm{d}$ in both years (Fig. 2, middle and bottom). Bakker et al. (2009) reported that daily $\mathrm{N}$ uptake of broccoli aboveground biomass varied over time and $\mathrm{N}$ application rates, ranging from 1 to $16 \mathrm{~kg} \mathrm{~N} / \mathrm{ha} / \mathrm{d}$, whereas Thompson et al. (2002) showed that $\mathrm{N}$ uptake by broccoli was $5 \mathrm{~kg} \mathrm{~N} / \mathrm{ha} / \mathrm{d}$ at the first bud growth stage. This high $\mathrm{N}$ demand in the midto late season may explain why OF application increased yields above cover crop alone.

Shoot N uptake (biomass N) at harvest increased linearly with fertilizer applications and by cover crops in 2006 at both sites (Fig. 1B). Regression line of each cover crop plot (X: OF rate $\mathrm{N} \mathrm{kg} \cdot \mathrm{ha}^{-1}, \mathrm{Y}$ : biomass $\mathrm{N} \mathrm{kg} \cdot \mathrm{ha}^{-1}$ ) was highly significant $(P<0.001$; Fig. 1B) and the effect of cover crop application was not observed in slopes but in intercepts at both sites $(P<0.05$, data not shown). The difference in intercepts between the cover crop plot and non-cover crop plot showed that cover crop application increased biomass $\mathrm{N}$ by $29 \mathrm{~kg} \mathrm{~N} / \mathrm{ha}$ at both sites when 160 (A) to 219 (B) $\mathrm{kg} \cdot \mathrm{ha}^{-1}$ of $\mathrm{N}$ was applied through cover crops. However, slopes of both regression lines for site $\mathrm{B}(\approx 0.59)$ were greater than those for site $\mathrm{A}(\approx 0.36)$ indicating that uptake of added fertilizer $\mathrm{N}$ was more efficient at B than at A. As discussed later, this may be attributed to lower native soil $\mathrm{N}$ fertility at $\mathrm{B}$ compared with A. At B in 2007, in contrast, biomass $\mathrm{N}$ increased curvilinearly with increasing rates of OF addition (Fig. 1B) and cover crops tended to reduce biomass $\mathrm{N}$ at harvest (Fig. 1B).

The amount of shoot biomass $\mathrm{N}$ at harvest varied widely from $53.9 \mathrm{~kg} \mathrm{~N} / \mathrm{ha}(\mathrm{B}, 2007$, cover crops $+0 \mathrm{~kg}$ N/ha plots) to $243 \mathrm{~kg} \mathrm{~N} / \mathrm{ha}$ (A, with cover crops $+252 \mathrm{~kg} \mathrm{~N} /$ ha plots). Studies of conventional broccoli production systems showed that the maximum $\mathrm{N}$ accumulation 
in aboveground biomass in broccoli was 157 to $465 \mathrm{~kg} \mathrm{~N} /$ ha with 250 to $537 \mathrm{~kg} \mathrm{~N} / \mathrm{ha}$ of N applications (Bakker et al., 2009; Kowalenko and Hall, 1987; Letey at al., 1983; Thompson et al., 2002; Zebarth et al., 1995). At similar N input levels, our biomass $\mathrm{N}$ data appears comparable with these data only for the 84 to 252 $\mathrm{kg} \mathrm{N} /$ ha treatments without cover crop plots at both sites in 2006. N immobilization at B in 2007 and low N recovery of cover crop N, as discussed subsequently, make all other plots inefficient in $\mathrm{N}$ recovery compared with conventional systems.

Apparent cover crop $\mathrm{N}$ recovery by broccoli varied among $\mathrm{N}$ treatments, sites, and years; the average recovery in A in 2006, B in 2006 , and B in 2007 was $20.9 \%, 15.1 \%$, and $-14.3 \%$, respectively (Fig. 3). Data from the both sites in 2006 were similar to the $20.7 \%$ found in another study in which N15 was used to track uptake of cover crop $\mathrm{N}$ by a subsequent lettuce crop (Jackson, 2000). The apparent recoveries of cover crop N for B in 2007, however, were negative for all but the highest fertility level, presumably as a result of net immobilization. Some other studies also found $\mathrm{N}$ immobilization to be an issue in the use of cover crops in broccoli production. Schroeder et al. (1998) reported that use of cowpea [Vigna unguiculata L. (Walp.)] as a cover crop for fall broccoli in Oklahoma was not recommended as a result of $\mathrm{N}$ tie-up by cowpea residues and a tendency of increased mortality of broccoli transplants in cowpea plots. In a transition field in Vermont, Schellenberg et al. (2009) found that broccoli yield was unaffected by various leguminous cover crop applications and a moderate rate of in-season $\mathrm{N}$ was recommended. $\mathrm{N}$ immobilization could be avoided by incorporating the cover crop at an earlier growth stage when the C:N ratio is lower (Diniz et al., 2007); however, this may not always be an option for growers, especially in central coastal California because spring rains and wet soil conditions can prohibit this practice.

The present study also underscored the critical need for appropriate supplemental $\mathrm{N}$ fertilization to achieve economically viable yields in the successive organic broccoli. Cover crops can reduce the need of $\mathrm{N}$ fertilization but could not satisfy the high $\mathrm{N}$ demand of broccoli. In cover crop plots, $\mathrm{N}$ fertilization increased head yield linearly up to $252-\mathrm{kg} \mathrm{N}$ plots at A and B in 2006. N application exceeding $252 \mathrm{~kg} \mathrm{~N} / \mathrm{ha}$ might have further increased the yield; however, higher rates may also risk unacceptably high losses from the system (Robertson, 1997) with little or no added economic return. For example, in a conventional broccoli production trial, Zebarth et al. (1995) reported 395 to $508 \mathrm{~kg}$ $\mathrm{N} /$ ha as the most profitable $\mathrm{N}$ rates when the maximum head yield was obtained at 504 to $518 \mathrm{~kg} \mathrm{~N} / \mathrm{h}$. They also recommended a lower $\mathrm{N}$ rate for broccoli than that required to maximize profit to obtain optimal head size and to minimize environmental risk, however. Similarly, Greenwood et al. (1980) obtained the maximum yield of broccoli (calabrese) at $\mathrm{N}$ rates $\approx 400 \mathrm{~kg} \mathrm{~N} / \mathrm{ha}$, whereas the maximum economic return was obtained at $\mathrm{N}$ rate of $248 \mathrm{~kg} \mathrm{~N} / \mathrm{ha}$.
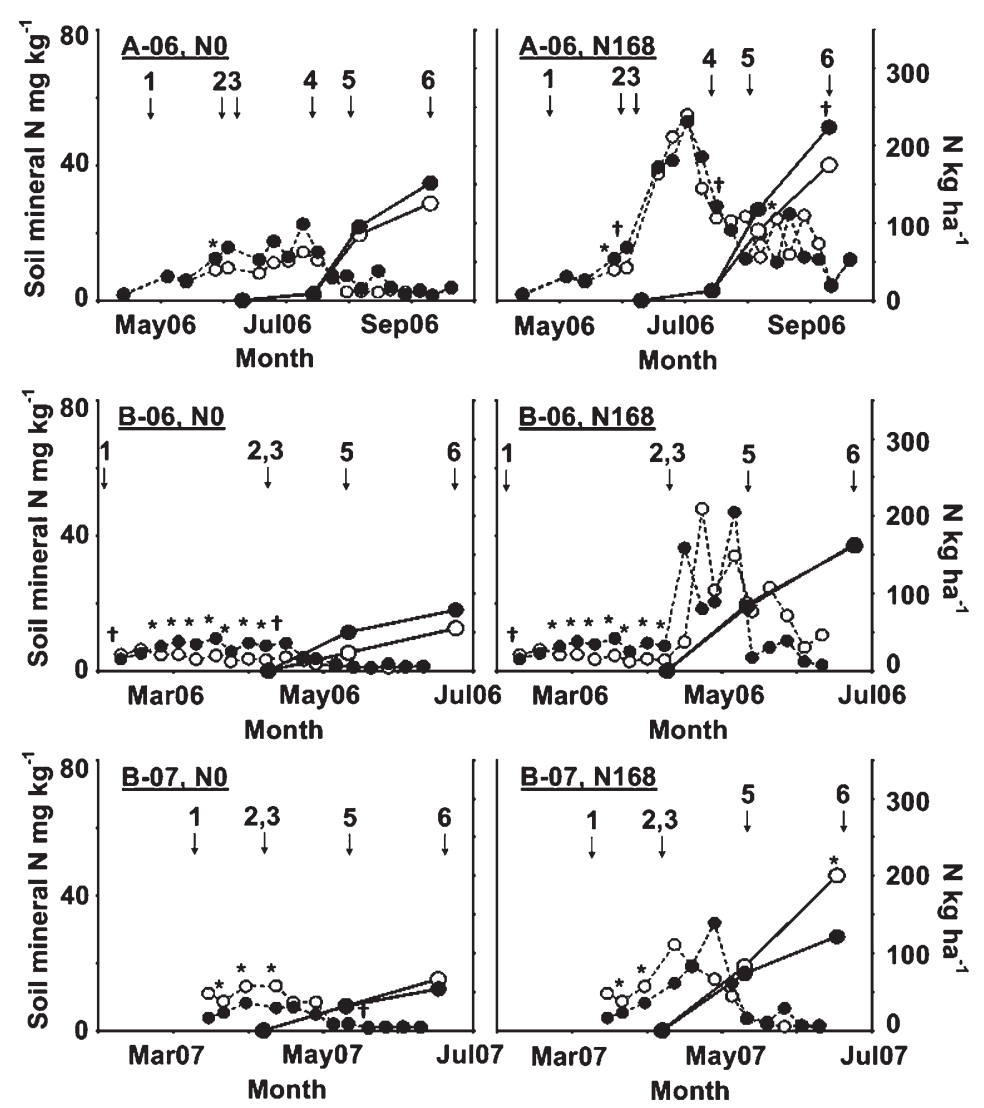

Fig. 2. Changes in mineral nitrogen $(\mathrm{N})$ content in topsoil (0- to 30-cm depth; dashed lines, left axis) and $\mathrm{N}$ in broccoli shoot biomass (solid lines, right axis) at Site A (top, A-06), Site B in 2006 (middle, B-06), and Site B in 2007 (bottom, B-07). Closed symbols are with cover crops and open symbols without cover crops. N0 and N168 represent organic fertilizer application rates in $\mathrm{kg} \mathrm{N} / \mathrm{ha}$. Arrows indicate the dates when major farming practices or tissue sampling were conducted. Events were: 1) cover crop incorporation; 2) pre-plant fertilizer application; 3) broccoli (trans)planting; 4) in-season N application (Site A only); 5) tissue sampling at first buds; and 6) broccoli harvest. $\dagger$,* Significant at $P \leq 0.10$, or 0.05 , respectively.

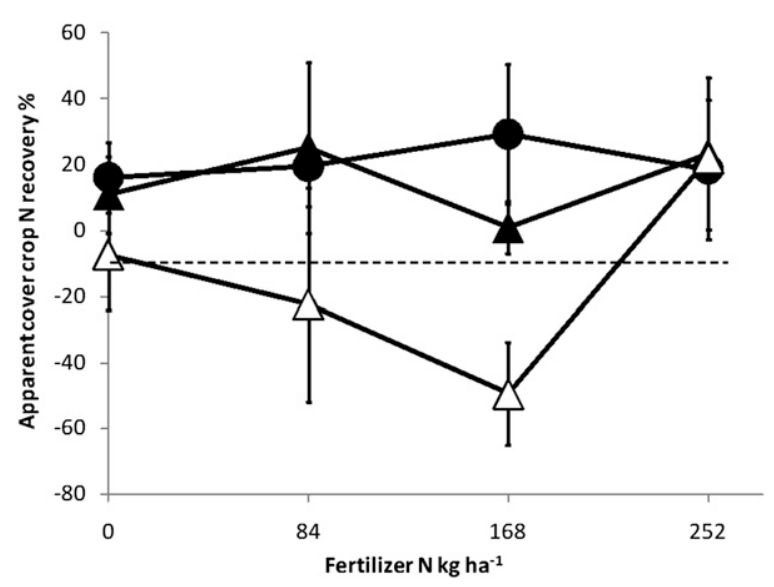

Fig. 3. Apparent cover crop nitrogen $(\mathrm{N})$ recovery by broccoli (\%) at Sites A and B. Closed circle symbols are Site A in 2006, closed triangle symbols are Site B in 2006, and open triangle symbols are Site B in 2007. Each point is the average of four replicates \pm SD. Apparent cover crop $N$ recovery $(\%)=\{[(\mathrm{kg} \mathrm{N} / \mathrm{ha} \mathrm{in}$ broccoli shoot biomass at $\mathrm{X} \mathrm{kg} \mathrm{N} / \mathrm{ha}$ fertilizer plot with cover crops $)-(\mathrm{kg} \mathrm{N} / \mathrm{ha}$ in broccoli shoot biomass at $\mathrm{X} \mathrm{kg} \mathrm{N} / \mathrm{ha}$ fertilizer plot without cover crops] $/ \mathrm{kg}-\mathrm{N} / \mathrm{ha}$ in cover crop aboveground biomass $\} \times 100$.

Apparent organic fertilizer $\mathrm{N}$ recoveries in our trials ranged from $20 \%$ to $92 \%$ and averaged $49 \%$ (Fig. 4). It was generally higher at Site B (59\% in 2006 and $55 \%$ in 2007) than at $\mathrm{A}(34 \%)$ reflecting the higher biomass $\mathrm{N}$ in the unfertilized control plots at A. This was lower than the recovery of chemical $\mathrm{N}$ fertilizers applied to broccoli, $74 \%$ at an $\mathrm{N}$ rate of 120 to $240 \mathrm{~kg} \cdot \mathrm{ha}^{-1}$ as reported by Vagen et al. (2007), but in a similar range to the $40 \%$ to $93 \%$ at $\mathrm{N}$ rates of 125 to $250 \mathrm{~kg} \cdot \mathrm{ha}^{-1}$ found by Zebarth et al. (1995).

Nitrogen supply from cover crops, fertilizers, and soil. Timing and availability of biomass $\mathrm{N}$ 
in cover crops depends in part on the $\mathrm{C}: \mathrm{N}$ ratio of the cover crop at incorporation with a C:N ratio of above 20 to 25 being likely to immobilize mineral $\mathrm{N}$ in soil for some period of time (Magdoff and van Es, 2000). For legume/ cereal mix cover crops, a similar relationship was found with its $\mathrm{N}$ content: if $\mathrm{N}$ content of the cover crops at incorporation is at or below $20 \mathrm{~g} \cdot \mathrm{kg}^{-1}$, the cover crop is likely to tie up soil
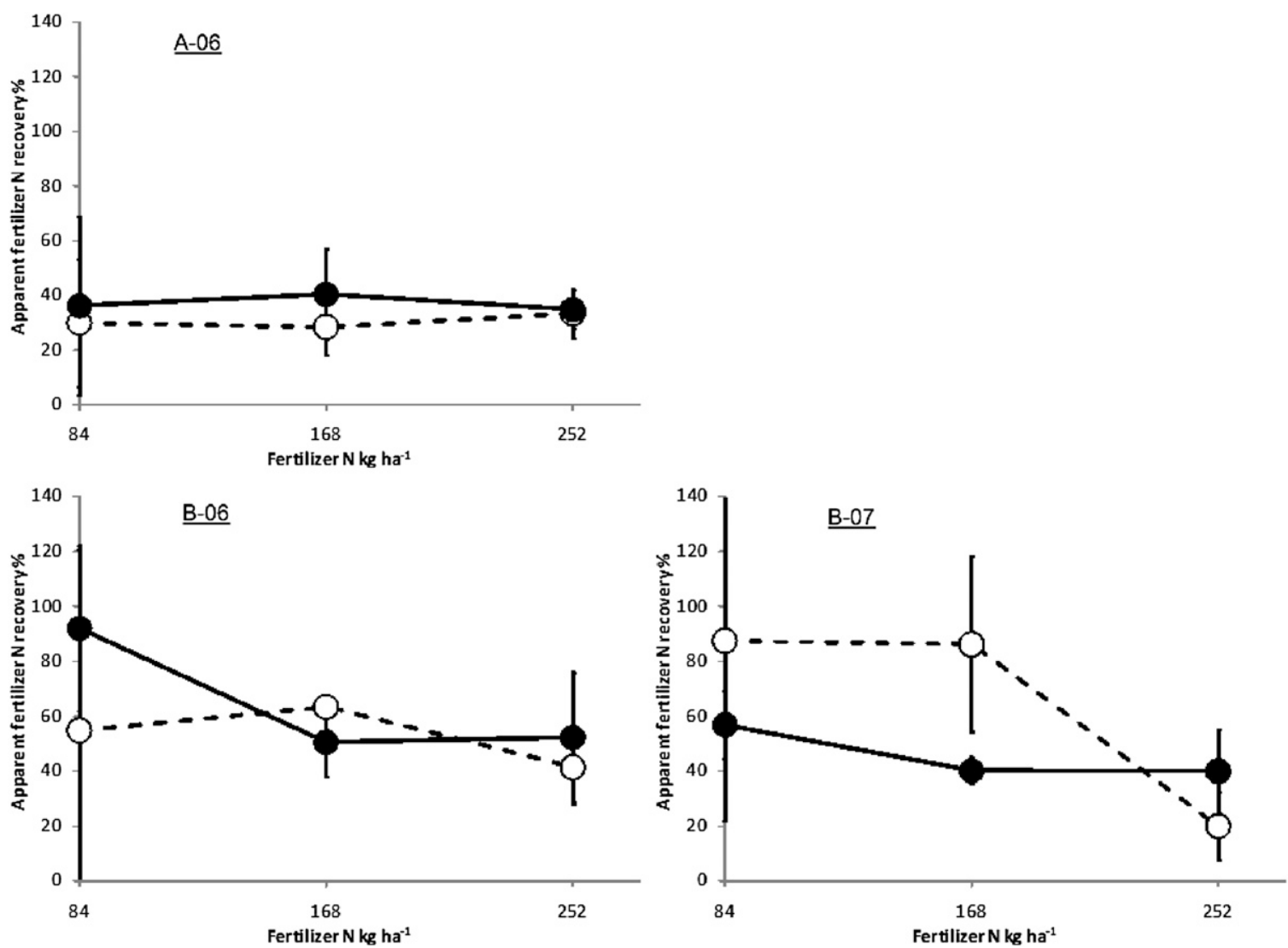

Fig. 4. Apparent organic fertilizer nitrogen (N) recovery by broccoli (\%) at Sites A and B. A-06; Site A (2006), B-06; Site B (2006), and B-07; Site B (2007). Closed symbols with a solid line are with cover crops and open symbols with a dashed line are without cover crops. Each point is the average of four replicates \pm SD. Apparent organic fertilizer $\mathrm{N}$ recovery $(\%)=\{[(\mathrm{kg} \mathrm{N} / \mathrm{ha}$ in broccoli shoot biomass at X kg N/ha plot $)-(\mathrm{kg} \mathrm{N} / \mathrm{ha}$ in broccoli shoot biomass at $0 \mathrm{~kg} \mathrm{~N} / \mathrm{ha}$ plot) $] / \mathrm{X} \mathrm{kg} \mathrm{N} / \mathrm{ha}\} \times 100$, where $\mathrm{X}$ is $\mathrm{N}$ application rate of fertilizer treatment.

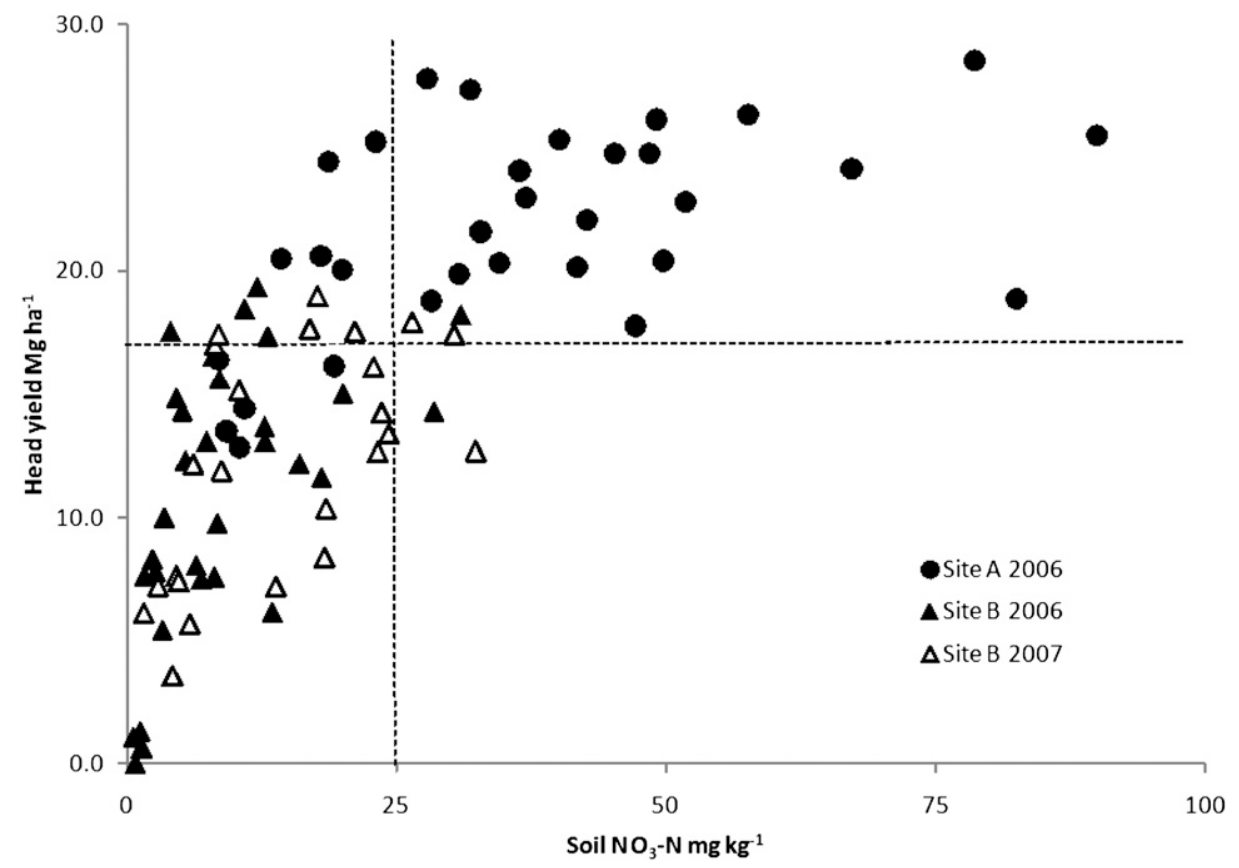

Fig. 5. Relationship between $\mathrm{NO}_{3}-\mathrm{N}$ content in topsoil ( 0 - to 30-cm depth) at 2 to 3 weeks from the pre-plant fertilization and broccoli head yield at Sites A and B Soil $\mathrm{NO}_{3}-\mathrm{N} 25 \mathrm{mg} \cdot \mathrm{kg}^{-1}$ is a common threshold for pre-side-dress nitrate test in deciding whether in-season N should be applied or not (Heckman, 2002). A horizontal dashed line indicates the average fresh broccoli yield (conventional + organic) of Monterey County $\left(17 \mathrm{Mg} \cdot \mathrm{ha} \mathrm{a}^{-1}\right)$. 
mineral $\mathrm{N}$ instead of releasing $\mathrm{N}$ (Hartz et al., 2005). This may explain why we observed $N$ release from the cover crops at Site B in 2006 ( $\mathrm{N}$ content $31 \mathrm{~g} \cdot \mathrm{kg}^{-1}$ ) and $\mathrm{N}$ immobilization by the cover crops at B in 2007 (N content: 21 $\left.\mathrm{g} \cdot \mathrm{kg}^{-1}\right)$. At A, however, the cover crop $\mathrm{N}$ content was also $21 \mathrm{~g} \cdot \mathrm{kg}^{-1}$ yet $\mathrm{N}$ appeared to be released soon after incorporation (Fig. 2). As discussed subsequently, this discrepancy may reflect the long history of organic management at this site (greater than 33 years) in that $\mathrm{N}$ mineralization of existing soil organic matter from the labile fraction may have provided sufficient $\mathrm{N}$ to support more rapid microbial breakdown of the cover crop residue without net immobilization.

Soil mineral $\mathrm{N}$ content increased as the fertilizer application rates increased regardless of site and year (Fig. 2). It peaked $\approx 2$ to 3 weeks after pre-plant fertilizer applications and decreased thereafter as broccoli shoot biomass $\mathrm{N}$ increased. At both sites in 2006 , cover crop incorporation also increased soil mineral $\mathrm{N}$ content until pre-plant organic fertilizers were applied; thereafter, OF fertilization overrode soil inorganic $\mathrm{N}$ dynamics obscuring the effect of cover crop on soil inorganic $\mathrm{N}$ content. However, at B in 2007, soil mineral N content was decreased by cover crop incorporation in 0 and $84-\mathrm{kg} \mathrm{N}$ plots, suggesting soil inorganic $\mathrm{N}$ was immobilized by incorporated cover crops. However, the trend was less clear in 168 and $252-\mathrm{kg} \mathrm{N}$ plots in which high $\mathrm{N}$ application might have compensated for $\mathrm{N}$ immobilization.

Soil mineral $\mathrm{N}$ levels in the controls (no cover crops + no fertilizer plots) provide a measure of $\mathrm{N}$ supply from soil organic matter. The average of soil mineral $\mathrm{N}$ during the broccoli growth period from control plots at A (6.7 $\left.\mathrm{mg} \cdot \mathrm{kg}^{-1}\right)$ was greater than those at B (3.1 $\mathrm{mg} \cdot \mathrm{kg}^{-1}$ for both years). The difference in the soil mineral $\mathrm{N}$ level between the two sites becomes much more apparent when the overall averages of all treatments during the broccoli growth period are compared (A: $25.2 \mathrm{mg} \cdot \mathrm{kg}^{-1}$ vs. B: $\left.9.9 \mathrm{mg} \cdot \mathrm{kg}^{-1}\right)$. The greater $\mathrm{N}$ supply may be attributable in part to the decomposition of cover crop roots in the A soil, from which cover crop aboveground residue was removed to create "without cover crop" plots. However, Sainju et al. (2005) found that $\mathrm{N}$ in roots of vetch/rye mixed cover crops in 0 - to $120-\mathrm{cm}$ depth was as low as 4 to $11 \mathrm{~kg} \mathrm{~N} / \mathrm{ha}$ and the $\mathrm{C}: \mathrm{N}$ ratio 19 to 32 when shoot biomass $\mathrm{N}$ was 84 to $310 \mathrm{~kg} \mathrm{~N} /$ ha and C:N ratio 10 to 32 . Furthermore, Puget and Drinkwater (2001) reported that roots of hairy vetch decompose slower than shoots and that roots improve soil structure, whereas shoots provide $\mathrm{N}$ for the next crop. Therefore, it may rather reflect higher pools of labile organic $\mathrm{N}$ and/or higher levels of microbial activity in a soil that has received annual additions of cover crops and periodic compost additions for 33 years. Long-term organic management has been shown to increase microbial activity and labile soil $\mathrm{N}$ pools in other studies (Fliessbach and Mader, 2000; Marriott and Wander, 2006; Poudel et al., 2001).

Potential of soil pre-side-dress nitrate test for organic broccoli. Across both sites and years, soil $\mathrm{NO}_{3}-\mathrm{N}$ content between 2 and 3 weeks after pre-plant fertilization showed a positive correlation with head yields up to $\approx 25$ $\mathrm{mg} \cdot \mathrm{kg}^{-1}$, soil $\mathrm{NO}_{3}-\mathrm{N}$ above which yield leveled off at a level exceeding the average organic broccoli yield for Monterey County (Fig. 5). This pattern is similar to that observed in conventional field/vegetable crop production, in which the pre-side-dress nitrate test (PSNT) has been successfully used for deciding whether in-season N is needed (Breschini and Hartz, 2002; Heckman, 2002; Magdoff, 1991), suggesting that a PSNT has potential for use as a $\mathrm{N}$ management tool in organic broccoli. In the PSNT, soil from 0- to $30-\mathrm{cm}$ depth is sampled when crops are still small and typically 20 to $25 \mathrm{mg} \cdot \mathrm{kg}^{-1}$ of $\mathrm{NO}_{3}-\mathrm{N}$ is used as a sufficiency threshold for many crops; exceeding the threshold means no in-season $\mathrm{N}$ is necessary. Breschini and Hartz (2002) showed that the PSNT worked well for N management for head lettuce in the central coast of California. PSNT also has an advantage for broccoli over tissue tests at first bud (e.g., Geraldson and Tyler, 1990), because data are obtained early enough for side-dress application of solid organic fertilizers. Although our trials were not designed to evaluate PSNT per se, our data provide a clear indication that a PSNT in organic broccoli systems may be useful as Heckman et al. (2009) suggested it in organic farming in general. Further studies are needed to confirm the sufficiency threshold.

Economic benefits of cover crops and organic fertilizers. Estimated net returns above harvest and fertility costs showed that the cover crop plots were more profitable than the no cover crop plots for A and B in 2006, whereas this result was reversed for B in 2007. For each site, the increase in $\mathrm{N}$ increased yield but at a greater rate for the no cover crop plots than for the cover crop plots (Fig. 6). Although net return values were much higher at $\mathrm{A}$ than $\mathrm{B}$ in 2006, the benefit from cover crops was greater at B than A at all fertility levels (Fig. 6). The benefit from cover crops decreased with the
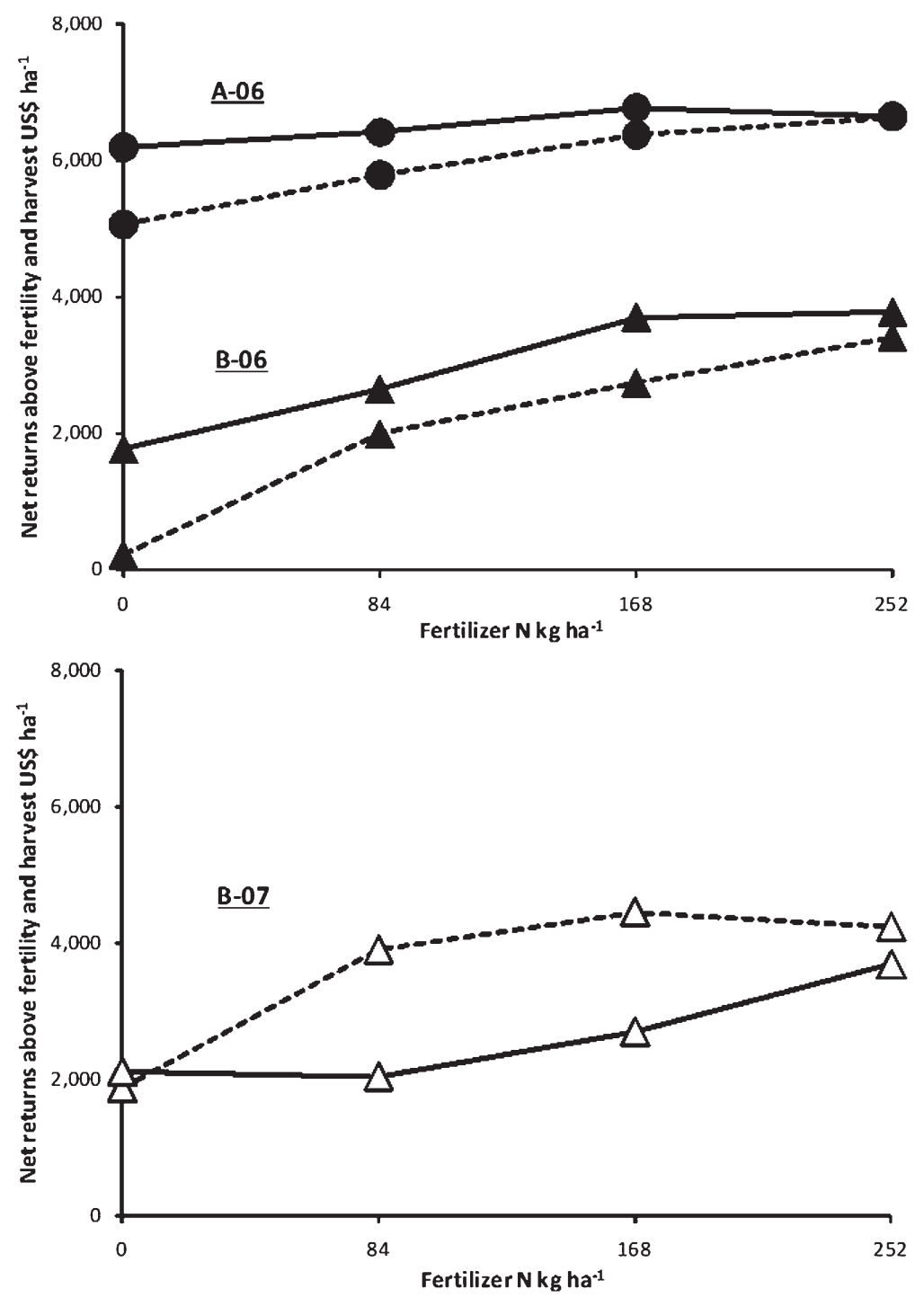

Fig. 6. Net returns per hectare above fertility and harvest costs at varying fertility rates and with and without cover crops. Closed circles, closed triangles, and open triangles indicate data for Site A in 2006, Site B in 2006, and Site B in 2007, respectively. Data with a solid line are with cover crops and data with a dashed line without cover crops. 
increase in fertilizer rates $(\$ 1131 /$ ha with no fertilizer and only $\$ 14 / \mathrm{ha}$ at $252 \mathrm{~kg} \cdot \mathrm{ha}^{-1}$ for A and \$1558/ha with no fertilizer and \$369/ha at $252 \mathrm{~kg} \cdot \mathrm{ha}^{-1}$ for B 2006), however. In contrast, at B in 2007, net returns from cover crop plots were reduced by $\$ 540$ to $\$ 1861 /$ ha from no cover crops plots in N 84 to $252 \mathrm{~kg} \cdot \mathrm{ha}^{-1}$ rates as a result of the lower yields in cover crop plots (Fig. 6).

For the no cover crop plots, the increase in net return attributable to fertilizer $\mathrm{N}$ decreased with increases in the rate of $\mathrm{N}$. In other words, the largest incremental increase in net returns was realized from going from 0 to $84 \mathrm{~kg} \mathrm{~N} / \mathrm{ha}$ (\$723, \$1776, and \$2028/ha for A in 2006, B in 2006, and B in 2007 with no cover crops, respectively). For the cover crop treatments, the change in net returns was greatest for all trials when the increase was from 84 to $168 \mathrm{~kg}$ $\mathrm{N} /$ ha. For A with cover crops, the net returns actually decreased when the $\mathrm{N}$ increased from $168 \mathrm{~kg} \mathrm{~N} / \mathrm{ha}$ to $252 \mathrm{~kg} \mathrm{~N} / \mathrm{ha}$. The yields at A did not increase with the additional $\mathrm{N}$ implying that the crop had adequate $\mathrm{N}$ from the combined cover crop and feather meal at $168 \mathrm{~kg} \mathrm{~N} /$ ha. Although the present study only accounted for the cover crop economic effect on yields and costs of the successive broccoli crop, future studies should evaluate long-term benefits of cover crop in a comprehensive manner so that multifunctions of cover crops can be evaluated.

In conclusion, adequate organic $\mathrm{N}$ fertilization in addition to cover crops is needed to achieve economically viable yield of organic broccoli grown after legume/cereal mixed winter cover crops. However, data suggest that cover crops can reduce the need for fertilizer $\mathrm{N}$ application in organic broccoli production, especially, as seen at A, at a field with a long history of cover crop-based organic management. Nitrate dynamics in topsoil showed that a PSNT looks promising as another tool for $\mathrm{N}$ management for organic broccoli. Use of cover crops increased net return above harvest and fertility costs when the yield reduction by $\mathrm{N}$ immobilization did not occur. However, the net return increase by the use of cover crops tended to diminish as the rate of organic fertilizer application increased. Evaluation of longterm economic contributions of cover crops as well as a comprehensive study of multiple functions of cover crops in this system warrants future research.

\section{Literature Cited}

Analytical Software. 2008. Statistix 9.0, Tallahassee, FL.

Bakker, C.J., C.J. Swanton, and A.W. McKeown. 2009. Broccoli growth in response to increasing rates of pre-plant nitrogen. II. Dry matter and nitrogen accumulation. Can. J. Plant Sci. 89:539-548.

Bensen, T.A., R.F. Smith, K.V. Subbarao, S.T. Koike, S.A. Fennimore, and S. Shem-Tov. 2009. Mustard and other cover crop effects vary on lettuce drop caused by Sclerotinia minor and on weeds. Plant Dis. 93:1019-1027.

Bibro, J.D. 1991. Cover crops for wind erosion control in semiarid regions, p. 36-38. In: Hargrove, W.L. (ed.). Cover crops for clean water: Intl. Conf., West TN Expt. Sta., Soil and Water Conservation Soc., Ankeny, IA.
Bremer, E. and C. Van Kessel. 1992. Plant-available nitrogen from lentil and wheat residues during a subsequent growing season. Soil Sci. Soc. Amer. J. 56:1155-1160.

Brennan, E.B., N.S. Boyd, R.F. Smith, and P. Foster. 2009. Seeding rate and planting arrangement effects on growth and weed suppression of a legume-oat cover crop for organic vegetable systems. Agron. J. 101:979-988.

Brennan, E.B. and R.F. Smith. 2005. Winter cover crop growth and weed suppression on the central coast of California. Weed Technol. 19:10171024.

Breschini, S.J. and T.K. Hartz. 2002. Presidedress soil nitrate testing reduces nitrogen fertilizer use and nitrate leaching hazard in lettuce production. HortScience 37:1061-1064.

California Department of Food and Agriculture 2010. Organic sales report. 2007. 20 Dec. 2010 $<$ http://www.cdfa.ca.gov/is/i_\&_c/organic.html $>$.

Cherr, C.M., J.M.S. Scholberg, and R. McSorley. 2006. Green manure approaches to crop production: A synthesis. Agron. J. 98:302-319.

Crews, T.E. and M.B. Peoples. 2005. Can the synchrony of nitrogen supply and crop demand be improved in legume and fertilizer-based agroecosystems? A review. Nutr. Cycl. Agroecosyst. 72:101-120.

Crozier, C.R., L.D. King, and R.J. Volk. 1998 Tracing nitrogen movement in corn production systems in the North Carolina Piedmont: A nitrogen-15 study. Agron. J. 90:171-177.

Cutcliffe, J.A. 1971. Effects of plant population nitrogen and harvest date on yield and maturity of single harvested broccoli. HortScience 6: 482-484.

Dabney, S.M. 1998. Cover crop impacts on watershed hydrology. J. Soil Water Conserv. 53:207-213.

Dabney, S.M., J.A. Delgado, and D.W. Reeves. 2001. Using winter cover crops to improve soil and water quality. Commun. Soil Sci. Plant Anal. 32:1221-1250.

Delate, K., C. Cambardella, and A. McKern. 2008. Effects of organic fertilization and cover crops on an organic pepper system. HortTechnology $18: 215-226$

Delgado, J.A., R.T. Sparks, R.F. Follett, J.L. Sharkoff, and R.R. Riggenbach. 1999. Use of winter cover crops to conserve soil and water quality in the San Luis Valley of South Central Colorado, p. 125-142. In: Lal, R. (ed.). Soil quality and soil erosion. Soil Water Conservation Soc. CRC Press, Ankeny, IA.

Diniz, E.R., R.H.S. Santos, S.S. Urquiaga, L.A Peternelli, T.P. Barrella, and G.B. de Freitas 2007. Green manure incorporation timing for organically grown broccoli. Pesquisa Agropecu. Bras. 42:199-206.

Dufault, R.J. and L. Waters. 1985. Interaction of nitrogen fertility and plant-populations on transplanted broccoli and cauliflower yields. HortScience 20:127-128.

Fageria, N.K., V.C. Baligar, and B.A. Bailey. 2005. Role of cover crops in improving soil and row crop productivity. Commun. Soil Sci. Plant Anal. 36:2733-2757.

Fliessbach, A. and P. Mader. 2000. Microbial biomass and size-density fractions differ between soils of organic and conventional agricultural systems. Soil Biol. Biochem. 32:757-768.

Gaskell, M. 2004. Nitrogen availability, supply and sources in organic row crops, p. 13-20. In: Univ. of Calif. Sustainable Agric. Res. Educ. Program (ed.). Proc. of the Calif. organic production and farming in the new millennium: A Res. Symp. 15 July 2004. Berkeley, CA.

Geraldson, C.M. and K.B. Tyler. 1990. Plant analysis as an aid in fertilizing vegetable crops, p. 549-562. In: Westerman, R.L. (ed.). Soil testing and plant analysis. 3rd Ed. Soil Sci. Soc. Amer., Madison, WI.

Gliessman, S.R. 1989. Allelopathy and agricultural sustainability, p. 69-80. In: Chou, C.H. and G.R. Waller (eds.). Phytochemical ecology: Allelochemicals, mycotoxins and insect pheromones and allomones. Institute of Botany, Taipei, Taiwan.

Greenwood, D.J., T.J. Cleaver, M.K. Turner, J. Hunt, K.B. Niendorf, and S.M.H. Loquens. 1980. Comparison of the effects of nitrogenfertilizer on the yield, nitrogen-content and quality of 21 different vegetable and agricultural crops. J. Agr. Sci. 95:471-485.

Harris, G.H. and O.B. Hesterman. 1990. Quantifying the nitrogen contribution from alfalfa to soil and 2 succeeding crops using N-15. Agron. J. 82:129-134

Hartz, T.K., P.R. Johnstone, E.M. Miyao, and R.M Davis. 2005. Mustard cover crops are ineffective in suppressing soilborne disease or improving processing tomato yield. HortScience 40:2016-2019.

Heckman, J.R. 2002. In-season soil nitrate testing as a guide to nitrogen management for annual crops. HortTechnology 12:706-710.

Heckman, J.R., R. Weil, and F. Magdoff. 2009. Practical steps to soil fertility for organic agriculture, p. 139-172. In: Francis, C. (ed.). Organic farming: The ecological systems. Amer. Soc. Agron., Crop Sci. Soc. Amer., Soil Sci. Soc. Amer., Madison, WI.

International Organization for Standardization. 1998 Soil quality-Determination of total nitrogen content by dry combustion ('elemental analysis') ISO 13878:1998. (E). The International Organization for Standardization, Genève, Switzerland.

Jackson, L.E. 2000. Fates and losses of nitrogen from a nitrogen-15-labeled cover crop in an intensively managed vegetable system. Soil Sci. Soc. Amer. J. 64:1404-1412.

Jones, R.T., L.A. Weston, and R. Harmon. 1991. Effect of root cell size and transplant age on cole crop yields. HortScience 26:688.

Kano, C., A.R. Godoy, A.R.O. Higuti, M.M. Castro, and A.I.I. Cardoso. 2008. Broccoli production in function of container type and seedling age. Ciencia E Agrotecnologia 32:110-114.

Karpenstein-Machan, M. and R. Stuelpnagel. 2000. Biomass yield and nitrogen fixation of legumes monocropped and intercropped with rye and rotation effects on a subsequent maize crop. Plant Soil 218:215-232.

Kaymak, H.C., F. Yarali, and I. Guvenc. 2009. Effect of transplant age on growth and yield of broccoli (Brassica oleracea var. italica). Indian J. Agr. Sci. 79:972-975.

Kleinbaum, D.G., L.L. Kupper, K.E. Muller, and A. Nizam. 1998. Applied regression analysis and other multivariable methods. Duxbury Press, Pacific Grove, CA.

Kowalenko, C.G. and J.W. Hall. 1987. Nitrogen recovery in single-harvested and multiple-harvested direct-seeded broccoli trials. J. Amer. Soc. Hort. Sci. 112:4-8.

Lachat Instruments. 1993a. Ammonia (Salicylate) in $2 \mathrm{M} \mathrm{KCl}$ soil extracts, QuikChem method 12-107-06-2-A. Milwaukee, WI.

Lachat Instruments. 1993b. Nitrate in $2 \mathrm{M} \mathrm{KCl}$ soil extracts, QuikChem method 12-107-04-1-B. Milwaukee, WI.

Ladd, J.N., M. Amato, R.B. Jackson, and J.H.A. Butler. 1983. Utilization by wheat crops of nitrogen from legume residues decomposing in soils in the field. Soil Biol. Biochem. 15:231-238.

Lamont, W.J. 1992. Transplant age has little effect on broccoli head weight and diameter. HortScience 27:848 
Letey, J., W.M. Jarrell, N. Valoras, and R. Beverly. 1983. Fertilizer application and irrigation management of broccoli production and fertilizer use efficiency. Agron. J. 75:502-507.

Liebman, M. and A.S. Davis. 2009. Managing weeds in organic farming systems: An ecological approach, p. 173-195. In: Francis, C.A. (ed.). Organic farming: The ecological systems. Agron. Soc. Amer., Crop Sci. Soc. Amer., Soil Sci. Soc. Amer., Madison, WI.

Magdoff, F. 1991. Understanding the Magdoff pre-sidedress nitrate test for corn. J. Prod. Agr. 4:297-305.

Magdoff, F. and H. van Es. 2000. Building soils for better crops. 2nd Ed. Sustainable Agriculture Network (SAN), Beltsville, MD.

Marriott, E.E. and M. Wander. 2006. Qualitative and quantitative differences in particulate organic matter fractions in organic and conventional farming systems. Soil Biol. Biochem. 38:15271536.

Monterey County Agricultural Commissioner. 2007. Monterey county crop report 2007. 20 Dec. 2010. <http://www.co.monterey.ca.us/ ag/pdfs/CropReport2007.pdf>.

Puget, P. and L.E. Drinkwater. 2001. Short-term dynamics of root- and shoot-derived carbon from a leguminous green manure. Soil Sci. Soc. Amer. J. 65:771-779.

Poudel, D.D., W.R. Horwath, J.P. Mitchell, and S.R. Temple. 2001. Impacts of cropping systems on soil nitrogen storage and loss. Agr. Syst. 68:253268.

Ranells, N.N. and M.G. Wagger. 1997. Grass-legume bicultures as winter annual cover crops. Agron. J. 89:659-665.

Robertson, G.P. 1997. Nitrogen use efficiency in row-crop agriculture: Crop nitrogen use and soil nitrogen loss, p. 347-365. In: Jackson, L.E. (ed.). Ecology in agriculture. Academic Press, San Diego, CA.

Sainju, U.M., W.F. Whitehead, and B.P. Singh. 2005. Biculture legume-cereal cover crops for enhanced biomass yield and carbon and nitrogen. Agron. J. 97:1403-1412.

Schellenberg, D.L., R.D. Morse, and G.E. Welbaum. 2009. Organic broccoli production on transition soils: Comparing cover crops, tillage and sidedress N. Renewable Agr. Food Systems. 24:85-91.

Schonbeck, M., S. Herbert, R. Degregorio, F. Mangan, K. Guillard, E. Sideman, J. Herbst, and R. Jaye. 1993. Cover cropping systems for brassicas in the northeastern United States. 1. Cover crop and vegetable yields, nutrients and soil-conditions. J. Sustain. Agr. 3:105-132.

Schroeder, J.L., B.A. Kahn, and J.Q. Lynd. 1998. Utilization of cowpea crop residues to reduce fertilizer nitrogen inputs with fall broccoli. Crop Sci. 38:741-749.

Scow, K.M., O. Sinasco, N. Gunapala, S. Lau, R. Venette, H. Ferris, and R.S. Miller. 1994. Transition from conventional to low-input agriculture changes soil fertility and biology. Calif. Agr. 48:20-26.

Seiter, S. and W.R. Horwath. 2004. Strategies for managing soil organic matter to supply plant nutrients, p. 269-293. In: Magdoff, F. and R.R. Weil (eds.). Soil organic matter in sustainable agriculture. CRC Press, Boca Raton, FL.

Smith, R.F. 1992. Nitrogen release from cover crops. Central coast family farm report, UC Cooperative Extension Newsletter, San Benito County, May.

Smith, R.F. In press. Cover crops for nutrient management in organic strawberry production on the central coast. In: Koike, S.T., C. Bull, M. Bolda, and O. Daugovish (eds.). Organic strawberry production manual, DANR Publication, Univ. of Calif. Oakland, CA.
Temple, S.R., D.B. Friedman, O. Somasco, H. Ferris, K. Scow, and K. Klonsky. 1994. An interdisciplinary, experiment station-based participatory comparison of alternative crop management systems for California's Sacramento Valley. Amer. J. Altern. Agr. 9:64-71.

Thompson, T.L., T.A. Doerge, and R.E. Godin. 2002. Subsurface drip irrigation and fertigation of broccoli: I. Yield, quality, and nitrogen uptake. Soil Sci. Soc. Amer. J. 66:186-192.

Tonitto, C., M.B. David, and L.E. Drinkwater. 2006. Replacing bare fallows with cover crops in fertilizer-intensive cropping systems: A meta-analysis of crop yield and $\mathrm{N}$ dynamics. Agr. Ecosyst. Environ. 112:58-72.

Tourte, L., R. Smith, K.M. Klonsky, and R.L. De Moura. 2004. Sample costs to produce organic broccoli-Central coast region 2004. Univ. of Calif. Coop. Ext. 20 Dec. 2010. <http://coststudies. ucdavis.edu/files/broccoliorgcc2004.pdf $>$.

USDA-NASS. 2009. The 2007 Census of agriculture, 4 Feb. 2009. <http://www.agcensus.usda. gov/Publications/2007/Full_Report/index.asp>.

Vagen, I.M., T.S. Aamlid, and A.O. Skjelvag. 2007. Nitrogen fertilization to broccoli cultivars at different planting times: Yield and nitrogen use. Acta Agr. Scandinavica Section B-Soil. Plant Sci. 57:35-44.

Wyland, L.J., L.E. Jackson, W.E. Chaney, K. Klonsky, S.T. Koike, and B. Kimple. 1996. Winter cover crops in a vegetable cropping system: Impacts on nitrate leaching, soil water, crop yield, pests and management costs. Agr. Ecosyst. Environ. 59:1-17.

Zebarth, B.J., P.A. Bowen, and P.M.A. Toivonen. 1995. Influence of nitrogen fertilization on broccoli yield, nitrogen accumulation and apparent fertilizer-nitrogen recovery. Can. J. Plant Sci. 75:717-725. 